\title{
Outcome and complications of self-administration of over-the-counter abortion pills: an observational study in a tertiary care hospital of a medical college in New Delhi
}

\author{
Anjali Singh, Sruthi Bhaskaran, Anshuja Singla*
}

Department of Obstetrics and Gynecology, UCMS, New Delhi, India

Received: 16 June 2021

Accepted: 12 July 2021

\author{
*Correspondence: \\ Dr. Anshuja Singla, \\ E-mail: dranshuja@gmail.com
}

Copyright: (c) the author(s), publisher and licensee Medip Academy. This is an open-access article distributed under the terms of the Creative Commons Attribution Non-Commercial License, which permits unrestricted non-commercial use, distribution, and reproduction in any medium, provided the original work is properly cited.

\begin{abstract}
Background: Due to unrestricted free availability of abortion pills, despite of national policies, guidelines and medical termination of pregnancy (MTP) act, unsafe abortions by self-administration of these drugs for termination of unwanted pregnancies without prescription are becoming common in our country, leading to associated morbidity and mortality. Methods: A prospective Observational study was done at Guru Teg Bahadur hospital, university college of medical sciences, New Delhi, from November 2019 to April 2020, in the department of gynecology and obstetrics, on women visiting the outpatient department and casualty department with the history of self-administration of medical termination pills without prescription. This study was done to study the outcome and complications occurring due to selfadministration of over-the-counter abortion pills that are freely available in the market. 95 women were included in study and data was collected regarding age, education level, parity, presenting complaints, complications and their management. Descriptive analysis of the collected data was done.

Results: In this study 95 women were included $71.6 \%$ took pills before 8 weeks of gestation, $1 \%$ took in second trimester. $46.3 \%$ landed up in incomplete abortion and $33.68 \%$ needed surgical evacuation, $8.42 \%$ had ectopic out, $2.1 \%$ had scar site pregnancy and $7.36 \%$ needed laparotomy, $1.05 \%$ had rupture uterus followed by abortion pill intake while $1.05 \%$ suffered from acute kidney injury (AKI). There was no ICU admission nor any mortality.

Conclusions: There is urgent need of strict legislation to curtail this bad practice and free availability of over-thecounter abortion pills which leads to unexpected morbidity and mortality, such drugs should be given only by health care providers under supervision, there is need of community level awareness so as to impart knowledge regarding this problem.
\end{abstract}

Keywords: Abortion pills, Over the counter, Self-administration

\section{INTRODUCTION}

Abortion is willful termination of the pregnancy before the period of viability. Excluding few instances, in most of the cases it is an outcome of an unwanted pregnancy. ${ }^{1}$ One of the most prevalent tragedies for womankind is the problem of unwanted pregnancies and unsafe abortions. Each year about 42 million induced abortions are estimated to be performed worldwide, out of these about 20 million are unsafe. ${ }^{2}$
Medical abortions play a crucial role in providing access to safe, effective and acceptable abortion care. Medical abortion with mifepristone and misoprostol is safe when consumed under medical supervision with success rate of 92 to $97 \%$, they are approved by US FDA and are in WHO essential drug list. ${ }^{3,4}$ Mifepristone is anti-progesterone and binds to progesterone receptors, Misoprostol is PGE 1 analogue and acts by cervical softening, dilatation and enhance uterine contractions and also aids in expelling products of conception. ${ }^{5,6}$ 
Termination of pregnancy in India is legalized under the MTP Act since 1971. Earlier, surgical methods were used however, with the introduction of various drugs, termination can also be done with medications and is legalized under the amended MTP act 2002, it is recommended up to 63 days of gestation.,8 Clear guidelines have been formulated by organizations like WHO and in India by FOGSI regarding the use of abortion pills. The MTP act of India permits that abortion pills be prescribed by only registered medical practitioners and not by non-allopathic doctors or by pharmacists. WHO recommends that person or facility prescribing abortion pills should have a backup health care facility in case of failed or incomplete abortion. ${ }^{9}$ In spite of such clear guidelines and recommendations, self-administration, unplanned and unwanted abortions are common despite medical advancement and wide availability of contraceptive methods. ${ }^{10}$

This study was done at Guru Teg Bahadur hospital, New Delhi, from November 2019 to April 2020, to assess the magnitude of the problem due to unsupervised intake of abortion pills, leading to complications like severe anemia, sepsis, shock, ectopic pregnancies, uterine rupture, hemorrhagic shock and maternal mortality.

\section{METHODS}

A prospective observational study was done at Guru Teg Bahadur hospital, university college of medical sciences, New Delhi, from November 2019 to April 2020, in the department of gynecology and obstetrics.

The women visiting the OPD and casualty department during this period, with the history of self-administration of medical termination pills without prescription were included in the study. By self-administration we mean that these pregnant women did not have any medical consultation with a registered medical practitioner and took abortion pills which were purchased from the pharmacy without any prescription either by self or by some close relative.

Women who presented with history of any surgical procedure after MTP pill intake or consumed pills after a medical practitioner's advice were not included in our study.

The aim of the study was to study outcome and complications occurred due to self-administration of overthe-counter abortion pills that are freely available in the market.

So, a total of 95 women were included in study and data was collected regarding their age, literacy status, awareness about contraception, occupation, socioeconomic status, marital status, parity, presenting complaints, complications and their management. Descriptive analysis of the collected data was done.

\section{RESULTS}

A total 95 cases were studied, following data were obtained.

The $34.7 \%$ of the women were in age group of $20-25$ years of age, while $4.2 \%$ women were below 19 years of age. Most of the women belonged to middle class socioeconomic status. $35.8 \%$ women were illiterate. $96.8 \%$ women were married and most of the women were housewives i.e., $78.9 \%$ indicating lack of knowledge to visit a medical practitioner for abortion. 90.52\% had awareness about different contraceptives available.

There were $8.42 \%$ primigravida and $89.47 \%$ third gravida or more indicating that MTP pills were consumed to get rid of unwanted pregnancy (Table 1).

Table 1: Distribution of women according to their parity.

\begin{tabular}{|l|l|}
\hline Parity & Frequency $(\%)$ \\
\hline Primigravida & $8(8.4)$ \\
\hline G2 & $2(2.1)$ \\
\hline G3 or more & $85(89.5)$ \\
\hline
\end{tabular}

The findings showed that $68(71.57 \%)$ consumed pills up to 8 weeks, maximum POG of self-intake was 18 weeks which was followed by failed abortion (Table 2).

Table 2: Gestational age at the time of pill intake.

\begin{tabular}{|ll|}
$\begin{array}{l}\text { Gestational age at the time of } \\
\text { pill intake (weeks) }\end{array}$ & Frequency $(\%)$ \\
\hline Early pregnancy up to 8 weeks & $68(71.6)$ \\
\hline$<\mathbf{8 - 1 0}$ & $20(21.1)$ \\
\hline$<\mathbf{1 0 - 1 2}$ & $06(6.3)$ \\
\hline $\mathbf{1 2 - 1 8}$ & $01(1)$ \\
\hline
\end{tabular}

$5.26 \%$ women presented with shock and majority of the women presented with either excessive bleeding per vaginum or irregular bleeding or spotting per vaginum. $2.10 \%$ women presented with other complaints such as fever or weakness. Patients who presented with profuse bleeding were managed immediately by surgical evacuation, while those with minimal bleeding per vaginum and minimal retained products of conception were given tablet misoprostol (Figure 1).

Most of the women had incomplete Abortion (46.31\%), $8.42 \%$ had Ectopic pregnancy, $2.10 \%$ has scar site pregnancy and $1.05 \%$ had ruptured uterus as shown in the Figure 2.

Surgical evacuation was needed in $33.68 \%$ cases while $12.63 \%$ needed blood transfusion with surgical evacuation. $31.57 \%$ patients did not need any intervention i.e., neither surgical nor medical (Table 3 ). 

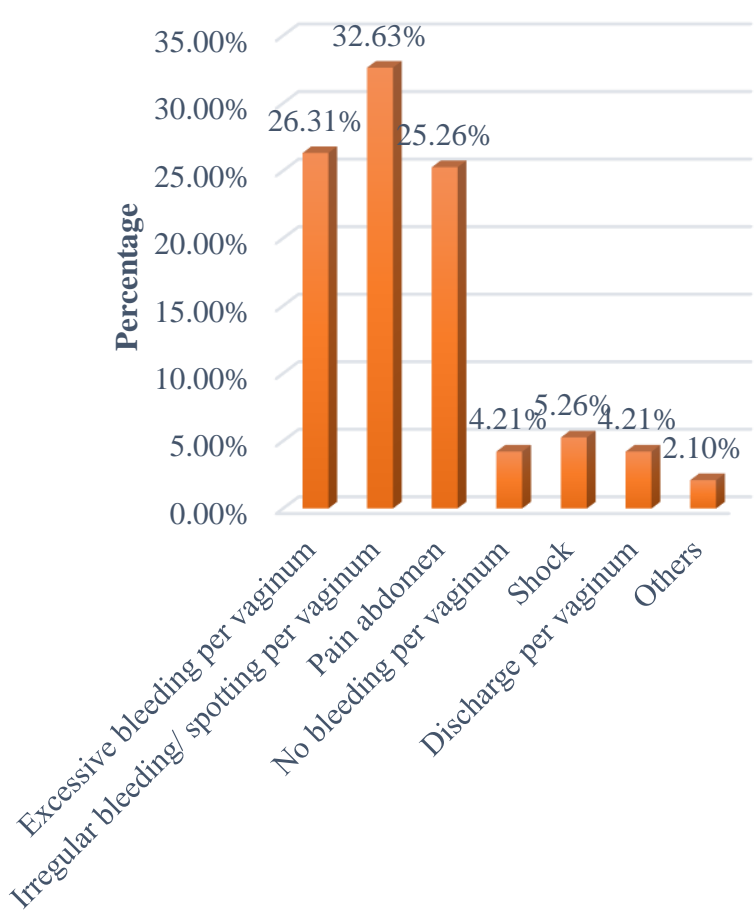

Presenting Complaints

Figure 1: Distribution according to the presenting complaints of the participants.

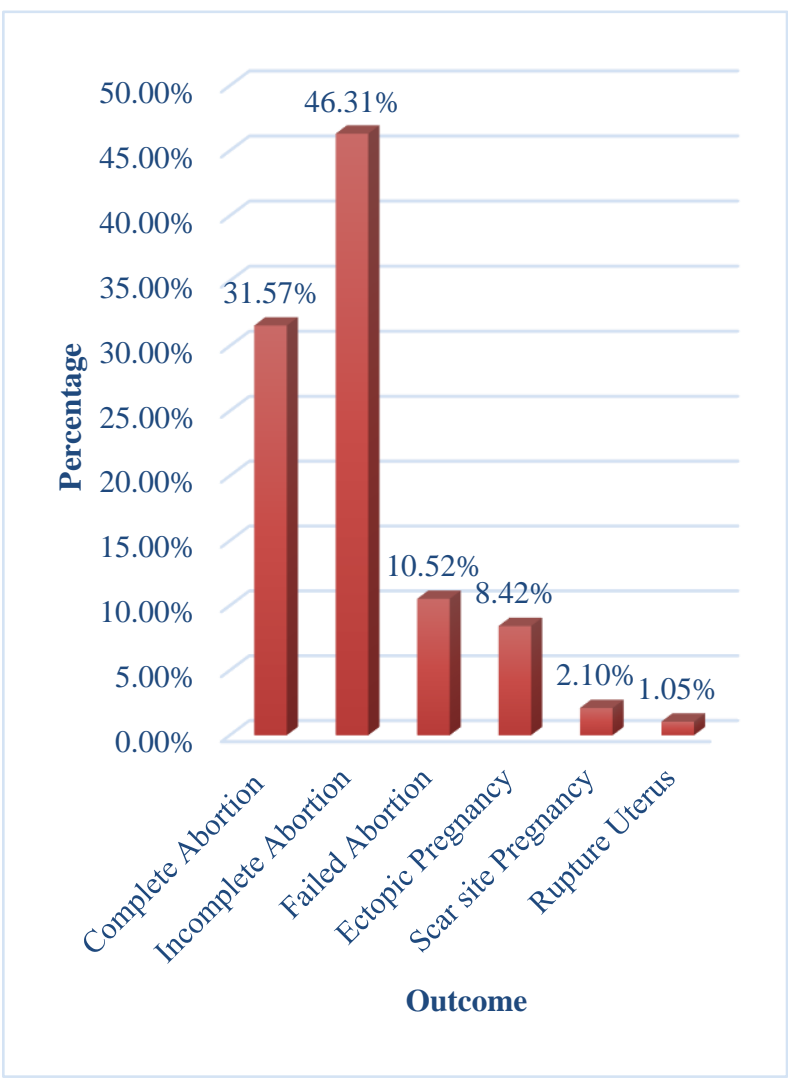

Figure 2: Distribution according to the outcome of self-administration of abortion pills.

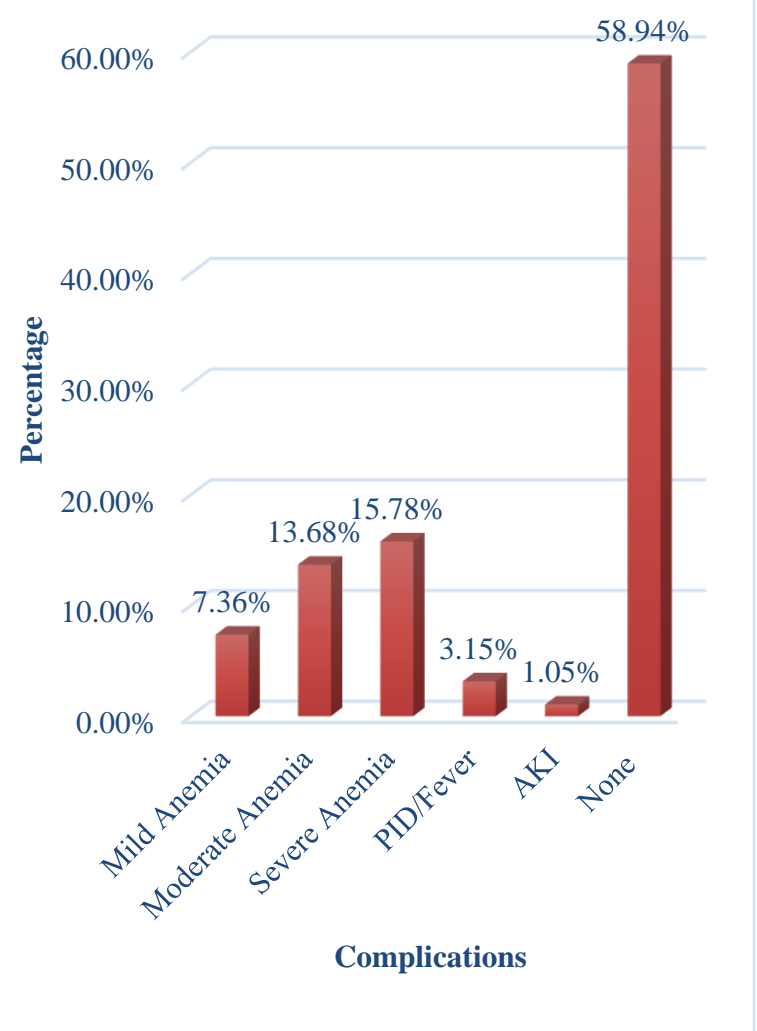

Figure 3: Distribution according to the complications occurred after self-administration of abortion pills.

Table 3: Distribution according to the management of complication.

\begin{tabular}{|ll|}
\hline Management of complications & Frequency (\%) \\
\hline Medical (misoprostol) & $17(17.89)$ \\
\hline No intervention & $30(31.57)$ \\
\hline $\begin{array}{l}\text { Surgical evacuation } \\
\text { Surgical evacuation with blood } \\
\text { transfusion }\end{array}$ & $20(21.05)$ \\
\hline laparotomies & $07(12.63)$ \\
\hline $\begin{array}{l}\text { Medical management of tubal } \\
\text { ectopic }\end{array}$ & $02(2.10)$ \\
\hline $\begin{array}{l}\text { Medical management of scar } \\
\text { pregnancy }\end{array}$ & $01(1.05)$ \\
\hline MTP & $05(8.42)$ \\
\hline Dialysis with sepsis & $01(1.05)$ \\
\hline
\end{tabular}

Table 4: Distribution of participants according to their awareness about contraception.

\begin{tabular}{|ll|}
\hline Contraception awareness & Frequency $(\%)$ \\
\hline Yes & $86(90.52)$ \\
\hline No & $09(9.47)$ \\
\hline
\end{tabular}

\section{DISCUSSION}

Widespread misuse of MTP pills which are freely available over the counter has become a threat to women of reproductive age group. In India, MTP act was passed 
in 1971 to prevent unsafe abortions with the aim of reducing maternal mortality and morbidity due to unsafe abortions. $^{11}$

As number of patients in present study were 95 over a time period of 6 months, Bajwa et al included 260 patients over a time of 2 years as compared to Thacker et al studied 37 women in one year. ${ }^{12,13}$ Maximum number of patients belonged to $20-25$ years of age and $91.57 \%$ were second or third gravidas, $90.52 \%$ were aware of contraceptive measures but didn't use any of the available options regularly. In present study $58.94 \%$ of cases had bleeding or spotting per vaginum as chief complaint, Thacker et al reported $89.1 \%$ patients presenting with bleeding per vaginum and $75.6 \%$ cases needed instrumental evacuation, while in present study $33.68 \%$ cases needed instrumental evacuation.

The $3.20 \%$ were unmarried and reason of not visiting to a doctor could be fear of social dishonor. Patients who consumed MTP pills after 12 weeks of gestation was only $1 \%$. Studies indicate that complications of second trimester is high with increased risk of surgical evacuation and infection and prolonged hospital stay we found that $10.52 \%$ were failed and $46.31 \%$ were incomplete, $7.36 \%$ landed up in laparotomies. ${ }^{14}$ Chances of failed abortion is $1 \%$ followed by medical abortion and chances of teratogenesis like moebius syndrome due to misoprostol, such pregnancies should be terminated. ${ }^{15}$

Present study had $8.42 \%$ ectopic pregnancies, Thacker et al had $5.4 \%$ while Bajwa et al $1.15 \%$ ectopic pregnancies. $^{12,13} 2.10 \%$ were scar site pregnancies and $1.05 \%$ had rupture uterus. Chances of scar site rupture in post cesarean section following first trimester medical abortion is non-existent but risk of rupture is $0.28 \%$ in second trimester. ${ }^{16}$ In present study $5.26 \%$ patients had reversible hemorrhagic shock, Thacker et al reported 5.4\% such cases with shock. ${ }^{13} \mathrm{We}$ found society is finding overthe-counter MTP very safe and convenient due to lack of awareness of contraceptive options and correct approach for termination of unwanted pregnancy.

\section{CONCLUSION}

There is urgent need of strict legislation to curtail this bad practice and free availability of over-the-counter abortion pills which leads to unexpected morbidity and mortality, such drugs should be given only by health care providers under supervision.

There is need of community level awareness so as to impart knowledge regarding this problem.

Health education must be given to the society regarding the need for medical counselling and supervision during an abortion and the risks of self-medication. Also, creating awareness regarding contraception to reduce unwanted pregnancy.

\section{ACKNOWLEDGMENTS}

The authors would like to thanks the contribution of the participants who gave their valuable time for completion of this study, also we wish to thank our obstetrics and gynecology department for all their support.

Funding: No funding sources

Conflict of interest: None declared

Ethical approval: The study was approved by the Institutional Ethics Committee

\section{REFERENCES}

1. Cunningham FG, Leveno KJ, Bloom SL, Haulh JC, Gilstrap LC, Wenstrom KD, editors. Abortion. Williams Textbook of Obstetrics, $24^{\text {th }}$ ed. New York: McGraw-Hill. 2014;215-31.

2. World Health Organization. Unsafe abortion, authors. Global and Regional Estimates of the Incidence of Unsafe Abortion and Associated Mortality in 2003. Geneva: World Health Organization. 2007;5. Available at: http://apps.who.int/iris/bitstream/handle/10665/4452 9/9789241501118_eng.pdf;jsessionid=BE550AB599 882C0EF486B92F7A06F5B8? sequence $=1$.

3. FOGSI focus on Medial abortion. FOGSI-ICOGGCPR guidelines (online) 2011. Available at: www.issuu com/fogsi/does/medical abortion. Accessed on 20 Feb 2021.

4. World Health Organization. Safe abortion: technical and policy guidelines for health systems. 2012;1-7. Available

at: www.apps.who.int/iris/bitstream/10665/709141/9 789241548434 eng.pdf. Accessed on 20 Feb 2021.

5. Bygdeman MSM. Progesterone receptor blockage. Effect on uterine contractility and early pregnancy. Contraception. 1985;32:45-51.

6. Swahn ML, Bygdeman M. The effect of the anitprogestin RU 486 on uterine contractility and sensitivity to prostaglandin and oxytocin. BJOG. 1988;95(2):126-34.

7. The medical termination of pregnancy amendment act. 2002;62.

8. International Consensus Conference on Non-surgical (Medical) Abortion in Early First Trimester on Issues Related to Regimens and Service Delivery. Frequently asked clinical questions about medical abortion. Geneva: World Health Organization. 2006. Available at: https://apps.who.int/iris/bitstream/handle/10665/278 968/9789241550406-eng.pdf

9. World Health Organization. Safe abortion: technical and policy guidelines for health systems. 2012;1-7. Available at: www.apps.who.int/iris/bitstream/10665/709141/9 789241548434 eng.pdf. Accessed on 20 Feb 2021.

10. Kaur Sukhwinder B, Singh Sukhminder Jit B, Kaur Gangdeep G, Nirankar S, Anita S, Goraya SPS. Medical abortion: is it a blessing or curse for the 
developing nations? Srilanka J Obstet Gynaeol. 2011; 33:84-90.

11. Government of India. The Medical Termination of Pregnancy Rules (Amendment). 2003. Ministry of Health and Family Welfare. New Delhi: Department of Family Welfare; 2003. Available at: http://www.mohfw. nic.in/index1. Accessed on 2015 Jun 11.

12. Bajwa SK, Bajwa SJS, Ghai GK, Singh N, Singh A, Goraya SPS. Medical abortion: is it a blessing or curse for the developing nations? Sri Lanka J Obstet Gynaecol. 2011;33(3):84-90.

13. Thaker RV, Deliwala KJ, Shah PT. Self-medication of abortion pill: women's Health in Jeopardy. NHL J Med Sci. 2014;3(1):26-31.
14. Maarit J, Maarit N, Satu S, Elina H, Mika G, Oskari H. Immediate adverse events after second trimester medical termination of pregnancy. Hum Reprod. 2011;26(4):927-32.

15. Courtney S, Mitchell C. Mifepristone in abortion care. Semin Reprod Med. 2005;23(1):82-90.

16. Goyal V. Uterine rupture in second trimester pregnancy termination in women with a prior caesarean delivery: a systematic review. Obstet Gynecol. 2009;113:1117-23.

Cite this article as: Singh $\mathrm{A}$, Bhaskaran S, Singla A. Outcome and complications of self-administration of over-the-counter abortion pills: an observational study in a tertiary care hospital of a medical college in New Delhi. Int J Reprod Contracept Obstet Gynecol 2021;10:3148-52. 